\title{
PENGARUH MODEL PEMBELAJARAN BRAINSTORMING TERHADAP SIKAP PERCAYA DIRI SISWA PADA PELAJARAN PPKN
}

\author{
Novyanti dan Alinurdin \\ Fakultas Keguruan dan Ilmu Pendidikan Universitas Pamulang \\ novyantik.nk@gmail.com
}

\begin{abstract}
The Brainstorming Learning Model is the right model for the type of students who are active but still lack confidence in expressing their opinions or ideas. The Brainstorming Learning Model motivates students to share their ideas without any pressure limit. The purpose of using this Brainstorming learning model is to find out whether there is a significant positive impact on the Brainstorming learning model on the self-confidence of students in Civics Class VIII lessons at Nurul Hidayah Islamic Junior High School Bojongsari Depok for the 2018/2019 academic year. This research is quantitative research. The instrument used in this research is a questionnaire. The data analysis technique used is regression correlation. The results showed that the Brainstorming learning model had an effect of $86 \%$ on self-confidence. It means that the brainstorming learning model can change students' self-confidence.
\end{abstract}

Keywords: Learning Model, Brainstorming, Confidence, PPKn.

\section{ABSTRAK}

Model Pembelajaran Brainstorming merupakan model yang tepat untuk tipe siswa yang aktif tetapi masih memiliki sikap kurang percaya diri dalam mengemukakan pendapat atau gagasan dan idenya. Model Pembelajaran Brainstorming memotivasi peserta didik untuk mencurahkan gagasan-gagasan yang mereka miliki tanpa ada batas tekanan. Tujuan penggunaan model pembelajaran Brainstorming ini adalah untuk mencari adakah dampak positif yang signifikan pada model pembelajaran Brainstorming terhadap perilaku percaya diri peserta didik dalam pelajaran PPKn kelas VIII di SMP Islam Nurul Hidayah Bojongsari Depok tahun ajaran 2018/2019. Penelitian ini adalah penelitian kuantitatif. Instrumen yang digunakan dalam adalah angket. Teknik analisis data yang digunakan adalah korelasi regresi. Hasil Penelitian menunjukan bahwa model pembelajaran Brainstorming berpengaruh sebesar 86\% terhadap sikap percaya diri. Itu berarti bahwa Model pembelajaran brainstorming dapat merubah sikap percaya diri peserta didik.

Kata Kunci: Model Pembelajaran, Brainstorming, Percaya Diri, PPKn

\section{PENDAHULUAN}

Pendidikan yaitu suatu proses pembelajaran untuk menumbuhkan kemampuan diri dengan cara memberikan dukungan dan menyediakan fasilitas kegiatan mereka. Proses pendidikan merupakan rangkaian dari sebuah proses pembelajaran. Dalam sebuah Pembelajaran yang efektif diperlukan sebuah proses pembelajaran yang sesuai, dimana kelas merupakan sarana pembelajaran yang menyenangkan dan memberikan kebebasan siswa mengungkapkan ide dan gagasannya serta guru mengeksplorasi kepercayaan diri peserta didik dengan menanamkan pemahaman yang bervariasi menggunakan berbagai macam model pembelajaran.

Pada kenyataannya yang terjadi di sekolah adalah proses pembelajaran banyak mengalami kendala, diantaranya yaitu guru harus memadukan antara teori dengan kehidupan nyata di masyarakat. Hal ini disebabkan kurangnya informasi serta ketidakmampuan guru dalam pengelolaan kelas dan memakai model pembelajaran yang tidak bervariasi. Kemampuan guru dalam mengajar harus menggunakan beraneka ragam cara 
sehingga peserta didik tidak bosan dan aktif di kelas. Guru berperan untuk membantu proses perkembangan peserta didik. Kegiatan mengajar akan berhasil dengan baik jika seluruh peserta didik ikut aktif di dalamnya.

Dari pengamatan awal di kelas VIII di SMP Islam Nurul Hidayah Bojongsari Depok, diperoleh permasalahan pembelajaran PPKn yang dialami oleh para siswa adalah: (1) Rendahnya perilaku peserta didik dalam pembelajaran PPKn ; (2) Bersikap acuh saat pembelajaran berlangsung; (3) kurang menyenangi terhadap pelajaran PPKn; (4) guru mengajarnya monoton (5) peserta didik masih diminta untuk merangkum pelajaran yang diajarkan; (6) Adanya pembatasan ide atau gagasan saat peserta didik melakukan presentasi; (7) Kebiasaan.

\section{KAJIAN LITERATUR}

Sebelum melakukan sebuah pengajaran di dalam kelas guru harus memilih model pembelajaran yang tepat sehingga tujuan pembelajaran akan tercapai. Model pembelajaran adalah suatu pola yang digunakan untuk membentuk kurikulum ( rencana pembelajaran jangka panjang ), merancang bahan-bahan pembelajaran, dan membimbing pembelajaran di kelas. Menurut Hamzah B. Uno (2010: 2) bahwa ada persepsi yang berhubungan dengan model pembelajaran, seperti yang dijelaskan dibawah ini:

1) Pendekatan adalah suatu kegiatan pembelajaran yang harus lakukan oleh pendidik agar tujuan pembelajaran tersebut dapat tercapai.

2) Sistem lebih bersifat prosedural yang ditempuh oleh guru supaya rencana yang telah disusun dapat tercapai.

3) proses dalam melaksanakan metode yang digunakan guru untuk memandu siswa.

Model pembelajaran harus dianggap sebagai kerangka kerja struktural yang juga dapat digunakan sebagai arahan untuk mengembangkan lingkungan dan aktifitas belajar yang kondusif. Model pembelajaran memiliki ciri - ciri sebagai berikut:

1) Berdasarkan teori pendidikan dan teori belajar dari para ahli tertentu.

2) Mempunyai misi atau tujuan pendidikan tertentu.

3) Dapat dijadikan pedoman untuk perbaikan kegiatan belajar mengajar dikelas.

4) Memiliki bagian - bagian model yang dinamakan: (a) urutan langkah - langkah pembelajaran (syntax); (b) adanya prinsip - prinsip reaksi; (c) sisitem sosial; dan (d) sistem pendukung.

5) Memiliki dampak sebagai akibat terapan model pembelajaran.

6) Membuat persiapan mengajar (desain instruksional) dengan pedoman model pembelajaran yang dipilihnya.

Model pembelajaran berdasarkan teori belajar, meliputi model interaksi sosial, model pemrosesan informasi, model personal, dan model pembelajaran modifikasi tingkah laku (behavioral).

Model Osborn Parne merupakan model pembelajaran yang disebut model proses pemecahan masalah kreatif. Model ini merupakan perangkat fleksibel yang dapat diterapkan untuk menguji problem -problem dan isu - isu nyata. Dikembangkan oleh pencipta "Brainstorming" Alex Osborn (1979) dan Dr. Sisney Parne (1992), enam tahap dalam model ini merepresentasikan prosedur sistematis dalam mengidentifikasi tantangan, menciptakan gagasan, dan menerapkan solusi- solusi inovatif. Melalui praktik dan penerapan proses tersebut secara berkelanjutan, siswa dapat memperkuat teknik - teknik kreatif mereka dan belajar menerapkannya dalam situasi - situasi yang baru. Langkah -langkah model brainstorming, antara lain:

1) Menemukan tujuan mengidentifikasi tujuan, tantangan, dan arah masa depan 
2) Menemukan fakta - mengumpulkan data tentang masalah, mengobservasi masalah seobjektif mungkin

3) Memecahkan masalah - menguji bebagai problem untuk memisahkannya menjadi bagian bagian yang lebih kecil, seraya menguraikan problem tersebut secara terbuka.

4) Menemukan gagasan - menciptakan sebanyak mungkin gagasan terkait dengan masalah tersebut, brainstorming.

5) Menemukan solusi - memilih solusi yang paling sesuai, dengan mengembangkan dan memilih kriteria untuk menilai apa saja solusi alternatif yang dianggap terbaik.

6) Penerimaan - membuat rencana tindakan.

Tidak seperti model pengurai masalah pada umumnya, model ini lebih menekankan pada kebutuhan untuk menunda hasil keputusan terhadap gagasan - gagasan dan solusi - solusi yang diperoleh sehingga ada keputusan akhir yang dibuat. Dengan demikian, rangkaian ide pada tahap ketiga tidaklah di interupsi, malahan berbagai solusi yang potensial justru diterima. Peran guru pada tahap ini sangat penting, yakni menciptakan lingkungan yang di dalamnya para peserta didik merasa nyaman dalam membuat gagasan gagasan. Yang dibutuhkan dalam brainstorming adalah kuantitas ide, bukan kualitas. Berbeda dengan debat, ide dari seseorang dapat dianggap (di dukung, dibatasi, dikurangi, atau tidak disepakati) oleh peserta lain, pada penerapan model Brainstorming pendapat orang lain tidak untuk ditanggapi. Model ini berdasarkan pendapat bahwa kelompok diskusi dapat mengajukan usul dan ide berkali kali. . Lalu peserta didik diajak untuk mengajukan saran apapun mengenai masalah tersebut. semua ide akan dianalisis dan dievaluasi. Bisa jadi pemecahan masalah yang tidak terduga akhirnya muncul. Menurut pendapat Morgan (Suprijanto,2009:122), bahwa
Brainstorming adalah cara berfikir yang kreatif sehingga memberikan sebuah pertimbangan untuk berpikir kreatif. . Peserta di dorong untuk mencurahkan semua ide dan gagasan yang ada di pikirannya dalam jangka waktu tertentu berkaitan dengan berbagai masalah, dan menunda penilaian selama curah pendapat berlangsung. Penilaian akan dilaksanakan pada sesi berikutnya dimana di semua ide dipilih, dievaluasi dan mungkin dilaksanakan.

Dengan demikian dapat disimpulkan bahwa model Brainstorming adalah diskusi kelompok dimana peserta didorong untuk mengemukakan gagasan, pendapat, informasi, pengetahuan, pengalaman serta ide - ide mengenai suatu kasus tanpa adanya evaluasi dari peserta lain.

Tujuan penggunaan model Brainstorming menurut M.Subana(2009: 106) ialah mengeluarkan semua pemikiran yang ada pada peserta didik dalam menanggapi suatu masalah yang diberikan guru kepadanya.

Menurut Utami Munandar (1985: 104) beberapa ketentuan yang harus diperhatikan pada model Brainstorming adalah:

\section{Keleluasaan dalam memberikan ide.}

Peserta didik harus yakin dalam mengemukakan gagasan apapun, yang aneh atau ide beda dari yang lain. Ia pun tidak perlu merasa terikat pada apa yang sudah berlaku sampai sekarang, pada kebiasaan - kebiasaan lama.

\section{Penegasan pada jumlah.}

Pada model curah pendapat diperlukan ide - ide sebanyak mungkin, karena semakin banyak ide atau gagasan maka makin besar pula kemungkinan bahwa di antara gagasan dan ide tersebut ada yang orisinil.

\section{Penundaan kritikan.}

Pada tahap penyampaian gagasan, maka tidak boleh ada kritikan. Sanggahan baru boleh diberikan setelah tahap pencetusan gagasan selesai. Tahapana selanjutnya adalah penilaian gagasan dan akan dipilih gagasan yang terbaik. . 
Keunggulan Brainstorming seperti: (1) partisipasi seluruh siswa. (2) membiasakan peserta didik berpikir dengan terorganisir (3) melatih peserta didik untuk selalu siap berpendapat yang berhubungan dengan masalah yang diberikan guru (4) ikut serta dalam menerima pelajaran, siswa yang pandai membantu siswa yang kurang (5) terjadi kompetisi yang sehat (6) anak merasa leluasa.

Sedangkan kelemahan - kelemahan yang perlu diatasi yaitu: (1) waktu yang terbatas. (2) siswa yang kurang paham akan tertinggal (3) Anak yang berkompeten akan lebih unggul. (4) menampung semua ide. (5) pendapatnya belum tentu benar 6) Belum mendapat solusi yang tepat 7) masalah bisa meluas

Proses pembelajaran yang kreatif dapat berdampak positif bagi sikap peserta didik, dan salah satu sikap positif yang muncul adalah sikap percaya diri karena dapat menstimulus otak peserta didik untuk berfikir lebih kreatif dan inovatif. Sikap yang terlihat pada diri peserta didik dapat beragam dari sebuah proses pembelajaran. Seseorang dapat menilai perilaku orang lain melalui sikap yang muncul. Menurut Cutlip dan Center (Leavitt, 1978)bahwa sikap adalah keinginan untuk memberikan respon terhadap masalah atau situasi tertentu. Sedangkan pengertian dari Percaya diri adalah bahwa diri merasa yakin pada kemampuan dan penilaian (judgement) diri sendiri dalam melakukan tugas dan memilih pendekatan yang efektif. Hal ini termasuk pegangan atas kemampuan menghadapi kehidupan luas yang menantang dan kepercayaan atas keputusan atau pendapatnya.semakin menantang dan yakin atas keputusan atau pendapatnya.Keyakinan pada diri yang tumbuh itulah yang membuat siswa mampu mengatasi setiap masalah yang akan dihadapi. Orang dengan rasa percaya diri tinggi maka akan terpancar dari sikap dan karakter pembawaan diri yang tenang., menurut John (jack) Callahan (2007:14) bahwa individual confident is the only one formula in your spirit bulding. to accomplish success you need some support of yourself. Hal ini berarti bahwa keyakinan diri akan menciptakan sebuah kesuksesan.

Percaya diri akan menumbuhkan keyakinan yang mantap. Seperti yang dikemukakan oleh Barbara De Angelis, yang menyatakan bahwa perasaan mampu melakukan sesuatu akan tumbuh seiring dengan terciptanya keyakinan itu sendiri. Ia akan terus melakukannya hingga adanya sebuah kepastian bahwa ia bisa melakukannya. Percaya diri memiliki dua macam yaitu: a) berani secara bathin, dan b) berani secara lahir. karakteristik percaya diri adalah:

1) Memiliki keteguhan hati.

2) Independen.

3) Yakin dalam mengambil keputusan.

4) Menghargai diri sendiri.

5) Rendah hati.

6) Cekatan.

Sebuah lembaga pendidikan merupakan lingkungan yang sangat berpengaruh

\section{METODOLOGI PENELITIAN}

Tujuan dari pengkajian ini untuk mencari adakah dampak dari model pembelajaran Brainstorming terhadap sikap percaya diri peserta didik pada pembelajaran PPKn kelas VIII di SMP Islam Nurul Hidayah Bojongsari Depok Tahun Ajaran 2018/2019. Pengkajian ini dilakukan di SMP Islam Nurul Hidayah Bojongsari Depok. Penelitian menggunakan pendekatan kuantitatif dengan metode Regresi untuk mengukur adakah dampak pada model pembelajaran Brainstorming terhadap sikap percaya diri. Populasi penelitian adalah seluruh kelas VIII yang ada dengan tujuan untuk dapat melihat adanya pengaruh pengajaran dengan menggunakan Brainstorming tersebut pada perilaku percaya diri siswa.

Pengaruh cara belajar brainstorming diukur dengan menggunakan kuesioner. perilaku percaya diri siswa dinilai dengan pernyataan dari siswa di sekolah yang berupa data nominal/nilai dari masingmasing anak pada masing-masing kelompok. Populasi dalam kajian ini 
adalah keseluruhan warga sekolah yang berada di lingkungan sekolah tersebut. Kajian yang memungkinkan peneliti melakukan generalisasi yaitu berjumlah 163 siswa dan subjeknya, yakni seluruh siswa kelas VIII SMP Islam Nurul Hidayah Bojongsari Depok yang diperlakukan dengan model pembelajaran Brainstorming yang terdiri dari 49 orang. Penelitian dilakukan pada semester genap di SMP Islam Nurul Hidayah Bojongsari Depok Tahun Pelajaran 2018/2019 selama 3 bulan yaitu Januari sampai April 2019.

Regresi linear sederhana digunakan untuk menjawab pertanyaan penelitian apakah terdapat pengaruh positif dan signifikan model pembelajaran brainstorming terhadap sikap percaya diri peserta didik.

\section{Uji Persyaratan Analisis}

Sebelum dilakukan analisis, data dipastikan harus memenuhi semua persyaratan yang ditetapkan mencakup : (1) residual memiliki rerata $=0$; (2) residual memiliki variansi konstan atau homogen; (3) tidak terjadi korelasi; (4) terdistribusi normal (Muhidin, 2019; Suyono, 2015).

\section{Uji Hipotesis}

Hipotesis yang diajukan: "diduga terdapat pengaruh positif dan signifikan model pembelajaran brainstorming terhadap sikap percaya diri siswa".

\section{Hipotesis Statistik}

Ho: $\beta 1<0$ : tidak terdapat pengaruh positif dan signifikan model pembelajaran brainstorming terhadap sikap percaya diri siswa".

Ha : $\beta 1>0$ :diduga terdapat pengaruh positif dan signifikan model pembelajaran brainstorming terhadap sikap percaya diri siswa".

Dengan kriteria pengujian, Ho ditolak ketika $\beta 1>0$ dan Ho gagal ditolak ketika $\beta 1<0$.

\section{HASIL PEMBAHASAN}

Dari hasil penelitian menunjukkan bahwa siswa sudah memiliki persepsi dapat mengikuti pembelajaran dengan model brainstorming dengan rata-rata rerata 104.69 , berarti rerata siswa kurang mampu mengikuti pembelajaran dengan brainstorming. Jumlah siswa yang memperoleh skor di atas rata - rata sebanyak 25 siswa (51\%) dan 24 siswa memperoleh skor di bawah rata - rata (49\%), menunjukkan sebagian siswa sudah mengikuti pembelajaran brainstroming. Mengingat model ini dianggap baru dilaksanakan, peroleh skor tersebut dianggap menjelaskan situasi bahwa model pembelajaran brainstorming cukup melibatkan siswa dalam kegiatan pembelajaran.

Untuk skor sikap percaya diri, nilai rata-rata yang diperoleh sebesar 110.45 termasuk dalam kategori kurang percaya diri (96-143), itu berarti siswa kurang begitu percaya diri dalam mengemukakan pendapat selama kegiatan pembelajaran berlangsung. Jumlah siswa yang memperoleh skor di atas rata-rata sebanyak 23 siswa $(46.9 \%)$ dan 26 siswa (53.1\%) memperoleh skor di bawah rata-rata. Meskipun dianggap rendah, tetapi perubahan sikap percaya diri dianggap sebagai hasil positif dari model pembelajaran brainstorming.

Pengujian statistik dengan regresi linear sederhana, menunjukkan bahwa model ini dapat memprediksi sikap percaya diri siswa. Hasil pengujian menunjukkan bahwa $86 \%$ sikap percaya diri siswa dipengaruhi secara positif dan signifikan oleh model pembelajaran brainstroming. Hal itu menunjukkan bahwa sikap percaya diri dapat dibentuk oleh model pembelajaran brainstorming. Dengan belajar mengemukakan pendapat di kelas, siswa belajar menata emosional mereka, bahwa mereka memiliki kemampuan yang dapat ditunjukkan kepada kelompok sosial, bahwa diri mereka memiliki kemampuan yang dapat diandalkan. Kepercayaan bahwa mereka memiliki kemampuan menjadi modal utama untuk membangun rasa percaya diri.

\section{KESIMPULAN}

Berdasarkan kajian dari data yang di dapat, khususnya pembahasan mengenai 
dampak model pembelajaran brainstorming pada bentuk percaya diri peserta didik dalam pembelajaran PPKn pada tingkat VIII di SMP Islam Nurul Hidayah Bojongsari Depok Tahun Pelajaran 2018/2019, maka peneliti dapat menrumuskan bahwa dari hasil penelitian menunjukkan peserta didik sudah dapat mengikuti pembelajaran dengan model brainstorming, Pengujian statistik dengan regresi linear sederhana, menunjukkan bahwa model ini dapat memprediksi sikap percaya diri pada siswa dengan hasil pengujian membuktikan bahwa $86 \%$ sikap percaya diri siswa dipengaruhi secara positif dan signifikan oleh model pembelajaran brainstroming. Perubahan sikap percaya diri yang dapat terlihat dari peserta didik yaitu mereka terlihat tidak malu terhadap teman-temannya dalam menyampaikan pendapat dalam diskusi dan lebih termotivasi dalam belajar PPKn. Hal itu menunjukkan bahwa sikap percaya diri dapat dibentuk oleh model pembelajaran brainstorming. Dengan belajar mengemukakan pendapat di kelas, siswa belajar menata emosional mereka, bahwa mereka memiliki kemampuan yang dapat ditunjukkan kepada kelompok sosial, bahwa diri mereka memiliki kemampuan yang dapat diandalkan. Kepercayaan bahwa mereka memiliki kemampuan menjadi modal utama untuk membangun rasa percaya diri.

\section{REFERENSI}

Aldily, R. 2017. The Power Of Social \& Emotional Intelligent. Yogyakarta: Psikologi Corner.

Arikunto, S. 2015. Penelitian Tindakan Kelas Edisi Revisi. Jakarta: PT.Bumi Aksara.

Fathurahman,P. 2010. Strategi Belajar Mengajar Melalui Penanaman Konsep Umum \& Konsep Islami. Bandung: PT.Refika Aditama.

Huda, M. 2017. Model - Model Pengajaran Dan Pembelajaran. Yogyakarta: Pustaka Pelajar.
Hulukati,W. 2016. Pengembangan Diri Siswa SMA. Gorontalo: Ideas Publishing.

Majid, A. 2013. Strategi Pembelajaran. Bandung: PT.Remaja Rosdakarya.

Morissan. 2017. Teori Komunikasi Individu Hingga Massa. Jakarta: PT. Prenada Media Grup.

Muhibbinsyah. 2017. Psikologi Belajar. Depok: Raja Grafindo Persada.

Nasution,S. 2000.Berbagai Pendekatan dalam proses Belajar \&Mengajar. Jakarta: PT.Bumi Aksara.

N.K Roestiyah. 2012. Strategi Belajar Mengajar. Jakarta: Rhineka Cipta.

Riduwan. 2018. Dasar-dasar Statistika edisi revisi. Bandung: Alfabeta.

Rusman. 2016. Model - Model Pembelajaran: Mengembangkan Profesionalisme Guru. Jakarta: Rajawali Pers.

Sanjaya,W. 2016. Strategi Pembelajaran Berorientasi Standar Proses Pendidikan. Jakarta: Prenadamedia Grup.

Sobur, A. 2003. Psikologi Umum. Bandung: Pustaka Setia.

Sudjana.2005. Metoda Statistika. Bandung: PT Tarsito.

Suhadi, O. 2018. Penguatan Pendidikan Karakter (PPK). Jakarta: Erlangga.

Sugiyono. 2018. Metode Penelitian Kuantitatif, Kualitatif dan $R \& D$. Bandung: PT.Alfabeta.

Suprijanto.2017.Pendidikan Orang Dewasa dari teori hingga aplikasi.Jakarta: PT.Bumi Aksara.

Sutikno, M.Sobry. 2010. Strategi Belajar Mengajar Melalui Penanaman Konsep Umum \& Konsep Islami.Bandung: $\quad$ PT.Refika Aditama 